\title{
Techno-Environ-Economical Analysis of Floating PV/On-Ground PV/Grid Extension Systems for Electrification of a Remote Area in India
}

\author{
Satya Prakash Makhija ${ }^{1}$. S. P. Dubey ${ }^{2} \cdot$ R. C. Bansal ${ }^{3,4}$ (D) Prasanta K Jena $^{5}$ \\ Received: 16 June 2020 / Accepted: 19 April 2021 / Published online: 30 April 2021 \\ (C) The Author(s), under exclusive licence to Springer Nature Singapore Pte Ltd. 2021
}

\begin{abstract}
Remote area electrification is a major concern for a government of any developing nation. India is also working for it but despite continuous efforts towards remote area electrification, several thousand households in India are un-electrified. Several schemes have been launched by Government for electrification of such areas through grid extension but still many areas have not been covered under the proposed schemes due to economic, environmental and geographical reasons. Narayanpur district in Chhattisgarh state of India has un-electrified regions and various issues like poor literacy, untreated water facility and lack of access to communication networks. In order to find viable option of electricity supply to this region, a case study has been performed for the feasibility of off-grid floating photovoltaic (PV) system, on-ground PV system and grid extension along with their comparative analysis with respect to certain parameters i.e. net present value (NPV), cost of energy (CoE), environment cleanliness and social acceptance. Floating PV and onground PV systems have been designed and simulated using System Adviser Model (SAM) software developed by National Renewable Energy Laboratory (NREL), USA. The results show that floating PV system has lowest CoE of $\$ 0.0598 / \mathrm{kWh}$ and least negative NPV of $\$ 185,431$ as compared to other two options. However, it is found that floating PV system achieves positive NPV of $\$ 38,968$ in 28th year of project life.
\end{abstract}

Keywords Renewable energy · Environment $\cdot$ Floating PV · Grid $\cdot$ Electrification $\cdot$ Rural

R. C. Bansal

rcbansal@ieee.org

Satya Prakash Makhija

satyapmakhija@gmail.com

S. P. Dubey

spdubeyfee@gmail.com

Prasanta K Jena

pkj.ped@gmail.com

ITM University, Raipur, Chhattisgarh, India

ICFAI University, Raipur, Chhattisgarh, India

3 Department of Electrical Engineering, University of Sharjah, Sharjah, United Arab Emirates

4 Department of Electrical, Electronic and Computer Engineering, University of Pretoria, Pretoria, South Africa

5 National Institute of Technology, Raipur, Chhattisgarh, India

\section{Introduction}

Electrification of remote villages in developing countries is a prime agenda for every government in order to set a path for development. Indian government also, in its National Electricity Plan 2016, had committed for universal access to electricity by the end of 2019 [1]. In this direction, there have been many schemes announced in India but a considerable numbers of people still live without access to electricity (World Energy Outlook, 2020) [2]. Majority of these people live in rural areas which are still waiting for electricity. Since electricity has become a basic need for human being, it is highly essential that electricity should reach un-electrified rural areas to make people cope up with the developing pace of the world.

This study has been performed for finding solution to issues of lack of electricity in some areas of Chhattisgarh state of India. Chhattisgarh state has high electrification rate but still several thousand households from rural and urban areas are un-electrified. Some of these households have been 
covered under Rajiv Gandhi Gram Vikas Yojna ${ }^{1}$ (RGGVY), Deen Dayal Upadhyaya Gram Jyoti Yojana ${ }^{2}$ (DDUGJY) and Decentralized Distributed Generation (DDG) schemes of Govt. of India for rural electrification. There are some areas in Bastar region which are not covered under any such scheme yet. Narayanpur district is one such region which came into existence in the year 2007 after it was carved out from Bastar district. As per world population projections 2020, Narayanpur district has least population of 159,395 in Chhattisgarh state. It has a very less rate of electrification because of its remote location. It has a literacy rate of $48.12 \%$. Also, only $7.6 \%$ primary and $24.8 \%$ upper primary schools have their access to electricity. Very less rural households have drinking water facility and treated tap water facility which leads to lots of health issues. The district has a very poor communication facility either it be landline, mobile phones or internet facility [3].

There are several reasons behind the lack of electricity in this area. The issues are as follows:

(i) The area has issues related to antisocial activities of left wing extremism (LWE) along with the poor transportation and communication.

(ii) Narayanpur has a forest cover of over $71 \%$ which leads to scattered population i.e. out of 4143 households, an average of only 28 households exist per village. This distributed population will increase the number of transmission and distribution lines if opted for grid extension.

(iii) Grid extension will require deforestation which surely causes a high right of way (ROW) cost. In Narayanpur district, as per the state government report [4], 4143 households require 3.3463 billion dollars for electrification, i.e. 0.808 million dollars per household. The another fact is that most of the population (about 70\%) live in these deep forests from where they collect their food, medicines and household materials. Thus, deforestation of these areas is not at all advisable for electrification from cost and social point of view.

In view of above discussed three reasons, renewable energy based distributed generation (DG) has been sought as viable option due to recent advances in renewable energy technologies and utility infrastructures [5]. These facts are the motivation behind the present work towards finding solution in terms of floating PV or on-ground PV system. The paper

\footnotetext{
${ }^{1}$ Rajeev Gandhi Gram Vikas Yojna was started in April, 2005 with an aim to provide electricity to poor families in India. Under this scheme, all the poor families are given free electricity connections. The $90 \%$ of financial grant provided to this scheme comes from central government.

${ }^{2}$ Deen Dayal Upadhyaya Gram Jyoti Yojana is a scheme of government of India and has aim to provide continuous electricity supply to rural areas. This was started in November 2014 by central government with a mission to electrify 18,452 rural and un-electrified villages.
}

also presents comparative analysis of floating PV and onground PV system with grid extension based on parameters like cost, reliability, effect on environment and social acceptance by the area people.

Solar energy system has been considered for analysis as it is one of the most promising renewable energy due to its clean and free availability over the years and once the system is installed it can be maintained by the local people only. One of the limitations associated with solar energy is that it suffers from the drawback of huge land requirement which is a major issue since it will require deforestation at huge scale and this may not be cost effective in the present case. Hence, floating PV system may be a feasible solution and it can be installed over available cannels, ponds and dam water reservoirs. These systems may save cost and reduce the social un-acceptance risk involved in deforestation. Floating PV systems produce greater power output since it has higher PV system efficiency due to cooling effect of water. Floating PV can also help in reducing water evaporation and retaining water quality.

Many researchers have worked and presented studies wherein the requirement of electricity in rural areas and its impact on the society development along with certain limitations have been discussed. Malakar [6] has given a qualitative approach to enhance the capabilities of people of Chittoor, Andhra Pradesh state of India by electrification and has discussed various social factors being affected badly in unelectrified villages. The author has given an insight of the drawbacks that exist in the political system and has suggested solutions to overcome these issues. Saxena et al. [7] have presented role of caste, tribe and religion in power consumption inequalities and differences in the use of Liquefied Petroleum Gas (LPG) as a clean cooking fuel in India. Aklin et al. [8] have conducted survey in six states of India and discussed about social acceptance to the off-grid solar technology in India. Various factors such as poverty, inequality and the new technology issues were discussed followed by its solutions suggested to Government for establishing clean form of solar energy for rural villages' electrification which will make a substantial improvement in socio-environment factor. Sahu et al. [9] have discussed different floating PV design options and given information regarding present floating PV availability in India. Choi [10] has given a comparative analysis between On-ground and floating PV system and concluded that floating PV system possess $11 \%$ more generating efficiency than that of On-Ground system. PV modules in floating system were found to have less temperature rise because of the cooling effects of water [10]. Gisbert et al. [11] have discussed the design aspects of floating systems and prepared both technical and economical feasibility of the system. Song et al. [12] proposed installation of floating PV system on mine pit lakes and calculated NPV, payback period and economical and technical parameters using SAM software and presented a comparative analysis between floating PV and 
an On-Ground system. Also, floating PV system proved reduction in GHG emissions twice as compared to On-land PV systems which were installed after deforestation.

Kumar et al. [13] presented 10 MW PV plant design aspects along with its annual performance parameter. They have calculated various types of power losses and performance ratios followed by results comparisons using PVsyst and PVGIS softwares. Adefarati et al. [14] have presented the benefits of using renewable energy sources for reliability, environment and economics parameters like cost of energy, life cycle cost, the annual cost of load loss and life cycle greenhouse gas emission cost. Razmjoo et al. [15] have performed technoeconomical analysis for combined utilization of solar, wind and diesel energy for supplying selected load of Semirom city of Iran and presented economic viability of renewable energy use. Kumar et al. [16] have designed a hybrid standalone Wind-PV-Battery system to supply electricity for technical university campus located in north-west Indian state Rajasthan and found that optimal generation unit price is compatible with grid extension case. Gorjian et al. [17] have presented extensive research on technical advancements, economics and environmental impacts of floating PV systems. They have performed deep analysis on CAPEX, levelized cost of energy (COE) and impact of local environment on PV module support structures.

It was found that there is requirement of work which will find the feasibility of electricity availability from different possible and potential ways based on internal rate of return (IRR), net present value (NPV), cost of energy (COE), social acceptance, impact on environment and $\mathrm{CO}_{2}$ emissions points of view. The presented work is different in the sense that it does comparison of three systems, i.e. floating PV, On-ground PV and Grid extension system, based on seven parameters which cover various cost, environment and social aspects.

\section{Proposed Site Assessment for Necessary Prior Information}

As discusses before, three systems have been analysis for their feasibility in terms of various parameters. The assessment of site for installation of a system is prime important before its design and simulation. The site has been assessed for necessary information regarding system requirements and need of electricity.

\section{Site Assessment for Grid Extension System}

Extension of grid line from nearest substation to village areas is a tedious job due to existence of dense forest region. Chhattisgarh state power transmission company limited (CSPTCL) has planned to install a $220 / 132 \mathrm{kV}$ substation in Narayanpur district. The power will be transmitted and distributed to un-electrified villages through this substation. This work will require deforestation of around $20 \mathrm{~km}$ area in length for grid extension.

\section{Solar Resource and Site Temperature Assessment}

The potential of solar radiations required for PV systems has been assessed by collecting the data from NASA meteorological department's website [18]. The average solar radiation at the project site is found to be $5.34 \mathrm{kWh} / \mathrm{m}^{2} /$ day. Month wise average daily radiations are shown in Fig. 1(a) where it can be seen that April and May are the months of higher radiations. The ambient temperature profile is shown in Fig. 1(b) which shows considerable variations season wise.

\section{Site Assessment for Floating PV System}

Floating PV systems are installed over water reservoirs, canals, rivers, etc. The present system has been proposed on P.V. Pakhanjor dam reservoir located in Narayanpur district, Chhattisgarh, India built across Godavari river. It has a length of $518 \mathrm{~m}$ and its reservoir surface area covers $18 \mathrm{~km}^{2}$ as seen in Fig. 2 which shows the satellite view of the project location [19]. The meteorological and other characteristics of the site are given in Table 1. The availability of this huge reservoir surface area of $18 \mathrm{~km}^{2}$ ensures the potential for the installation of a floating PV system of sufficiently large capacity equal to $2.5 \mathrm{MW}$ which will certainly fulfil the electricity requirement of people of this area to a great extent.

\section{Site Assessment for on-Ground System}

There is enough ground space present in the area for installation of On-ground PV system. Here, installation of PV system on 12.7 acre ground will require deforestation of more than $70 \%$ of the land. Different types of trees present in forests of Bastar are Sal, Teak, Bijasal, Sirsa, Palas, Kusum, Imli, Mahua, Harra, Tendu, Salai, Kanha, Dhowara, and Achar [20].

\section{Technical and Economical Data for Various Systems Design}

For performance analysis of all the three systems, various technical and economical data have been used. These data are detailed in next sections for individual systems separately.

\section{On Ground PV System}

The configuration of On-ground PV system is shown in Fig. 3. DC voltage generated from PV modules is fed to electrical load of households of village after conversion into AC 
Fig. 1 a Month wise average daily radiations. b Ambient Temperature profile at selected project location

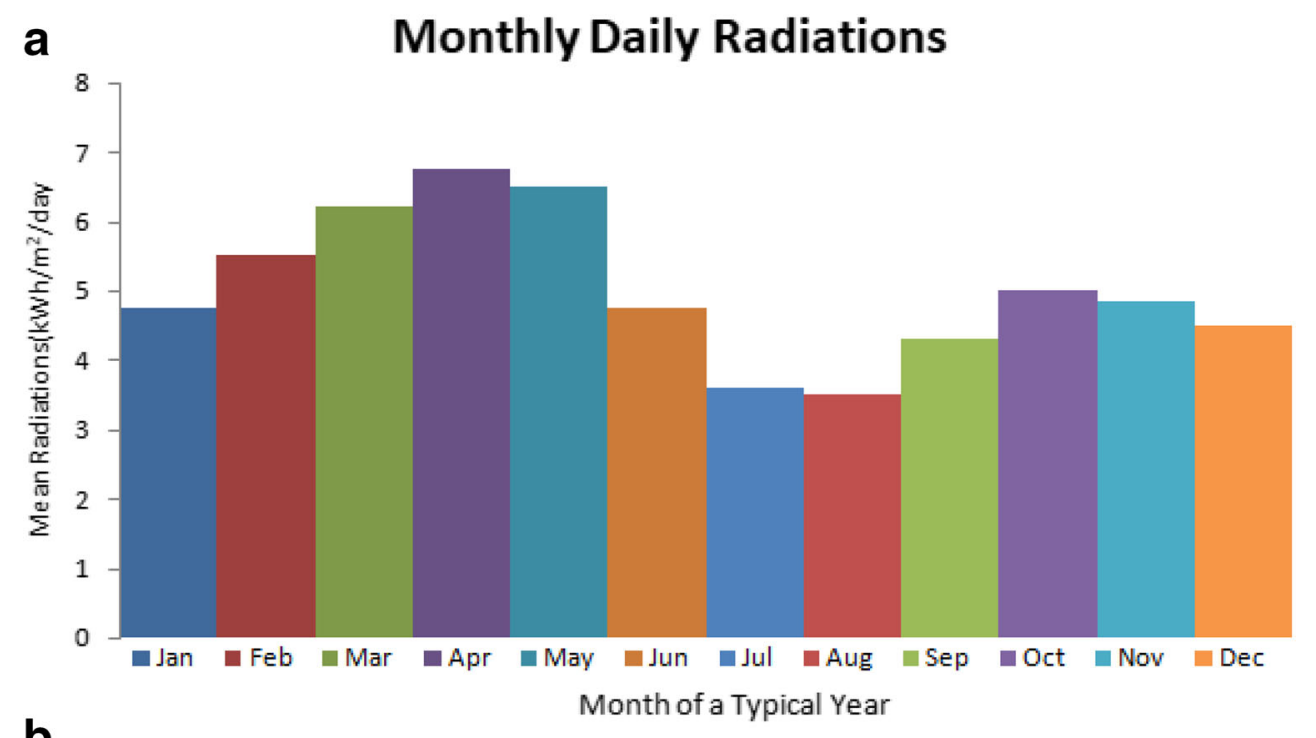

b

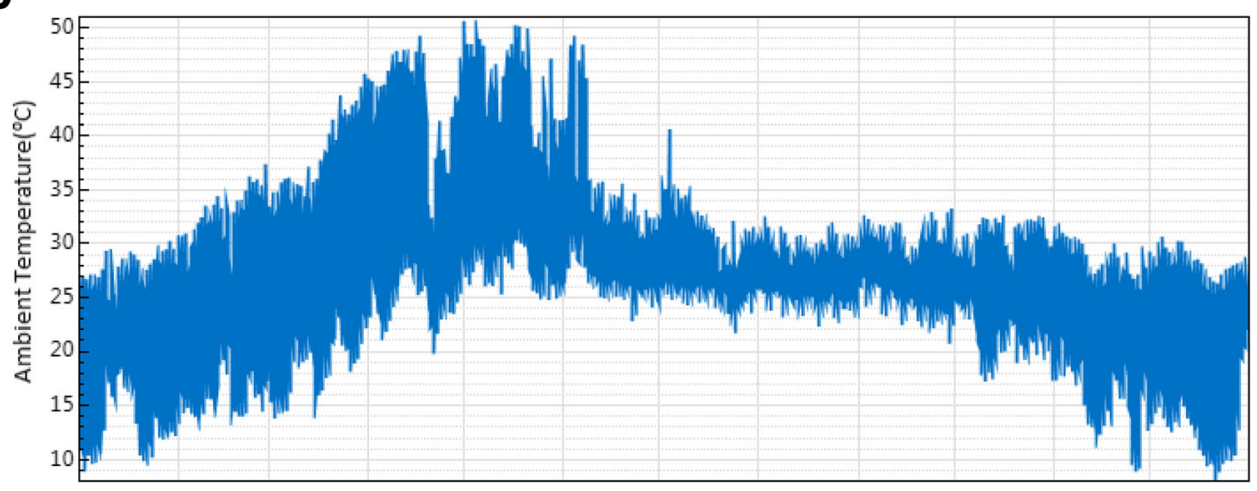

through inverter. Extra power generated is used to charge battery bank which gives power to village load during night hours when PV power is not available.

The PV modules used have following specifications [21]:

\begin{tabular}{lccc}
\hline Material: & $\mathrm{C}-\mathrm{Si}$ & $\begin{array}{c}\text { Maximum power } \\
\text { voltage: }\end{array}$ & $\begin{array}{c}38.8 \\
\mathrm{Vdc}\end{array}$ \\
\hline Nominal efficiency: & $16.21 \%$ & Open circuit voltage: & $\begin{array}{c}47.8 \\
\mathrm{Vdc}\end{array}$ \\
Maximum power: & $\begin{array}{c}0.2 \\
\mathrm{kWdc}\end{array}$ & Short circuit current: & $5.6 \mathrm{Adc}$ \\
$\begin{array}{l}\text { Maximum power } \\
\text { current: }\end{array}$ & $\begin{array}{l}5.2 \mathrm{Adc} \\
\end{array}$ & \\
\hline
\end{tabular}

The cost of PV modules and inverter along with their details of number of units is shown in Table 2 [21].

The lead-acid battery bank has capacity of $2150.9 \mathrm{kWh} \mathrm{dc}$ with a cost of $144 \$ / \mathrm{kWh}$. This makes total cost of battery bank equal to $\$ 309,726.69$. The technical details of battery bank are as follows:

- Desired battery bank voltage: $230 \mathrm{~V}$
- Fully charged cell voltage: $12 \mathrm{~V}$

- Cell capacity: 8962 Ah

- Total number of cells: 20

The On-ground PV system requires land purchase charges along with its preparation and transportation charges due to huge deforestation work. Required land area and its cost details are as follows:

- $\quad$ Required land area $=12.7$ acres

- Land purchase cost $=\$ 4607.7 /$ acre

Table 1 Meteorological and other parameters

\begin{tabular}{ll}
\hline Item & Value \\
\hline Latitude $\left(^{\circ}\right)$ & 19.74457 \\
Longitude $\left(^{\circ}\right)$ & 81.18935 \\
Monthly average direct normal radiation $\left(\mathrm{kWh} / \mathrm{m}^{2} /\right.$ day) & 5.00 \\
Surface area $\left(\mathrm{km}^{2}\right)$ & 18 \\
Height (meter) & 5.36 \\
Length (meter) & 518 \\
\hline
\end{tabular}


Fig. 2 Satellite view of the reservoir location

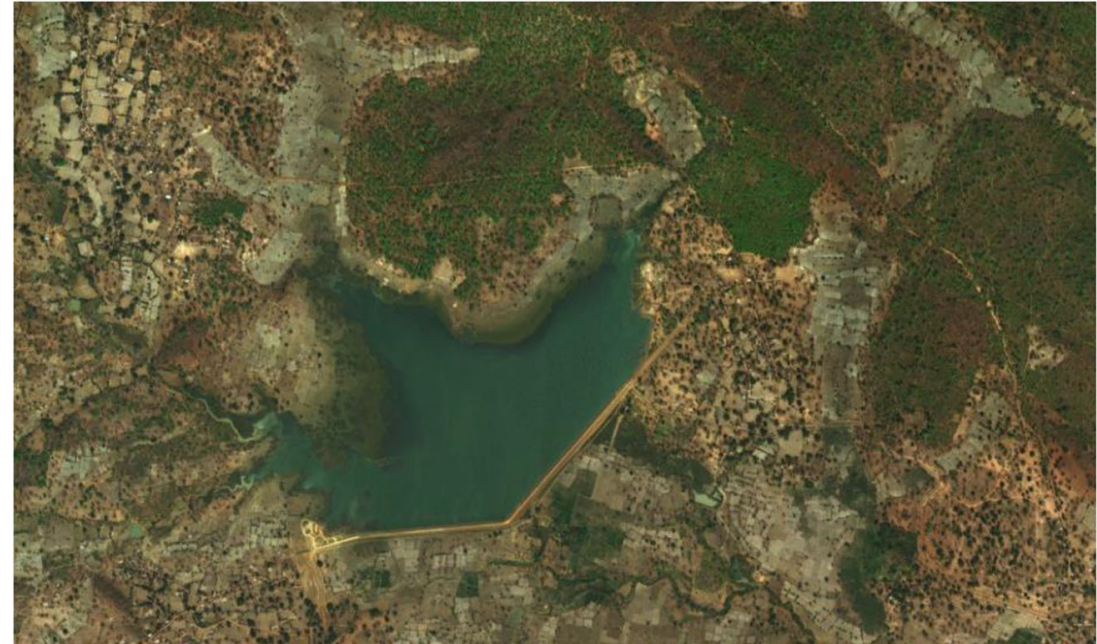

- Land preparation and transmission charges $=\$ 32,253.9 /$ acre

- Total land cost (including purchase and preparation \& transportation charges) $=\$ 468,082.59$

To find the number of modules, number of inverters, spacing between arrays, etc., various mathematical equations have been used by SAM. These equations [22] are described as follows:

Total number of modules is calculated by

$\mathrm{M}_{\mathrm{total}}=\left[\frac{\mathrm{V}_{\max }+\mathrm{V}_{\min }}{2}\right] / \mathrm{V}_{\mathrm{mod}}$

$\mathrm{S}_{\text {parallel }}=\left[(\mathrm{C} * 1000 \mathrm{~W} / \mathrm{kW}) / \mathrm{P}_{\max }\right\} / \mathrm{M}_{\text {total }}$

where $\mathrm{V}_{\max }$ and $\mathrm{V}_{\min }$ are the maximum and minimum maximum power point tracking (MPPT) voltage in the inverter. $\mathrm{V}_{\text {mod }}$ represents voltage corresponding to maximum power. $\mathrm{S}_{\text {parallel }}$ is the number of strings in parallel and $\mathrm{P}_{\max }$ is the maximum module power.

Total numbers of inverters required are given by.

$$
\left(\operatorname{Inv}_{\text {total }}\right)=\left(\mathrm{M}_{\text {total }} * \mathrm{~S}_{\text {parallel }} * \mathrm{P}_{\text {max }} \text {-mod }\right) /\left(\mathrm{R}_{\text {ratio }} * \mathrm{P}_{\text {inv-max }}\right)
$$

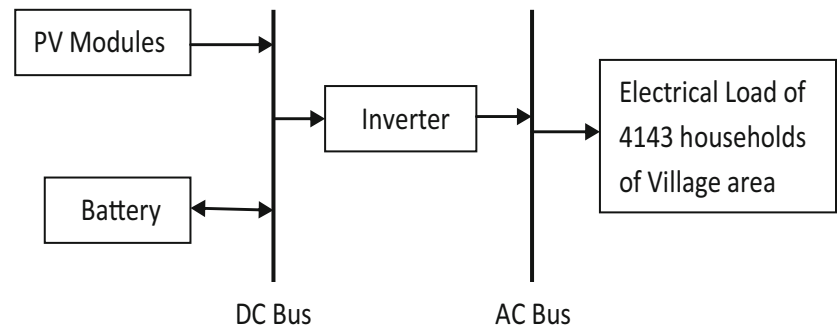

Fig. 3 PV system configuration
Here, $\mathrm{P}_{\text {max-mod }}$ is the maximum module power, $\mathrm{R}_{\text {ratio }}$ represents the ratio of $d c$ to ac power and has been given value 1.0. $\mathrm{P}_{\text {inv- max }}$ is inverter's maximum ac power. The spacing between arrays has been calculated as

$\mathrm{X}_{\text {spacing }}=\left\{\sin (\right.$ tilt $) * \tan \left(\right.$ Lat $\left.+23.5^{\circ}\right)+\cos ($ tilt $\left.)\right\} * \mathrm{~L}$

Here, $\mathrm{L}$ is the length of module and tilt is the tilt angle in degree.

Total area of the solar site can be calculated after the array spacing and tilt angle of each string is determined

Required area $=\left(\mathrm{M}_{\text {total }} * \mathrm{M}_{\mathrm{width}}\right) * \mathrm{X}_{1} * \mathrm{~S}_{\text {parallel }}$

\section{Floating PV System}

SAM doesn't have facility to simulate floating PV systems which have installation structures different and costlier as compared to that of On-ground PV systems. The values of technical and cost parameters considered for PV modules, inverter and battery bank are same as those in the Onground system. The capital expenditure including installation cost is 1.2 times more than that of On-ground system [10] because of the requirement of special frames and supporting system to make it floating. A typical floating structure is shown in Fig. 4 [22]. Land cost is eliminated in case of floating PV system, since it is distributed over the water. Thus, total capital expenditure is calculated to be $\$ 3,009,248$. The power output of floating PV system is experimentally found to be $11 \%$ more than the On-ground system [10] due to lower surrounding temperature above water surface.

\section{Grid Extension System}

The grid extension system cannot be designed and simulated in SAM. As per socio economical analysis carried out by 
Table 2 Cost details of PV modules and inverters

\begin{tabular}{llllll}
\hline Device & $\begin{array}{l}\text { No. of } \\
\text { units }\end{array}$ & $\begin{array}{l}\text { Power in } \\
\text { kWdc/unit }\end{array}$ & $\begin{array}{l}\text { Total power rating } \\
(\mathrm{kWdc})\end{array}$ & $\begin{array}{l}\text { Cost in } \\
\$ / \mathrm{Wdc}\end{array}$ & $\begin{array}{l}\text { Total cost } \\
(\$)\end{array}$ \\
\hline $\begin{array}{c}\text { PV } \\
\text { module }\end{array}$ & 12,393 & 0.2 & 2500 & 0.49 & $1,224,783$ \\
\begin{tabular}{l} 
Inverter \\
\hline
\end{tabular} & 568 & 4.0 & 2272 & 0.50 & $1,249,778$ \\
\hline
\end{tabular}

Chhattisgarh state and central government of India jointly, a power grid line to electrify 4123 households is required to be erected and commissioned. The grid line has not been considered for erection till now because of inaccessibility issues, security concerns and un-acceptance of local people to deforestation. The state government has demanded $\$ 6.65$ billion from Indian central government to be used for solving discussed issues and electrification. Thus it is estimated that $\$ 0.808$ million per household will be the expenditure on average basis.

\section{Results and Discussions}

\section{On-Ground PV System Simulation Results}

The On-ground PV system was designed and simulated using SAM software in which various technical and economical data were used as described in previous section. The Month wise daily average electricity in $\mathrm{kW}$ from PV system to the selected village load is shown in Fig. 5. As seen, during the lower temperature months from October to March, the power output is higher as compared to summer and rainy season months. The project lifetime was assumed to be 25 years and the economical data, i.e. EBITDA and annual costs along with annual energy production is shown in Table 3. The zero year is the year of capital investment at the starting of the project and thus the annual cost is shown negative for this time stamp. It can be seen that EBITDA and annual energy production is reducing as the PV system gets older with increasing time stamp. This is due to the fact that PV module efficiency reduces with time and thus lower energy output affects the EBITDA also.

\section{Floating PV System Simulation and Calculated Results}

In floating PV system design, all the technical parameters related to the system components were kept same as those of on-ground PV system. After simulation in SAM with project lifetime of 25 years, EBITDA and annual costs along with
Fig. 4 Floating PV supporting structure

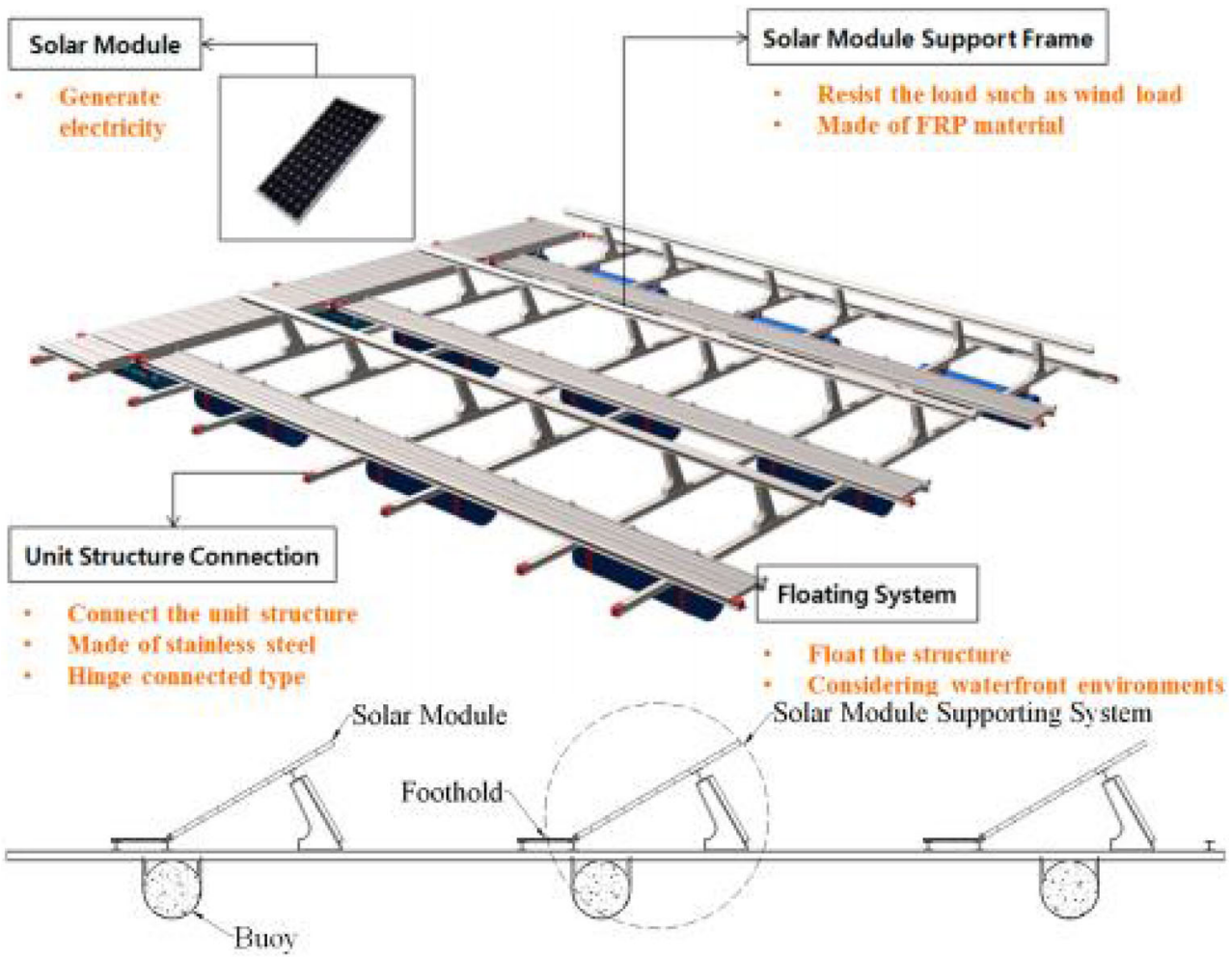


Table 3 Earnings, costs and energy produced during Onground PV system lifetime of 25 years

\begin{tabular}{llllllll}
\hline $\begin{array}{l}\text { Time } \\
\text { stamp }\end{array}$ & $\begin{array}{l}\text { EBITDA } \\
(\$)\end{array}$ & $\begin{array}{l}\text { Energy obtained } \\
\text { from simulation } \\
(\mathrm{kWh})\end{array}$ & $\begin{array}{l}\text { Annual } \\
\text { costs }(\$)\end{array}$ & $\begin{array}{l}\text { Time } \\
\text { stamp }\end{array}$ & $\begin{array}{l}\text { EBITDA } \\
(\$)\end{array}$ & $\begin{array}{l}\text { Energy obtained } \\
\text { from simulation } \\
(\mathrm{kWh})\end{array}$ & $\begin{array}{l}\text { Annual } \\
\text { costs }(\$)\end{array}$ \\
\hline $\begin{array}{c}\text { Zero } \\
\text { ye- }\end{array}$ & 0 & 0 & $-3,294,160$ & 13 & 169,580 & $3,665,190$ & $-131,997$ \\
ar & & & & & & & \\
1 & 175,769 & $3,892,420$ & $-178,887$ & 14 & 167,646 & $3,646,870$ & $-137,302$ \\
2 & 176,159 & $3,872,960$ & $-181,928$ & 15 & 165,417 & $3,628,630$ & $-142,870$ \\
3 & 176,421 & $3,853,590$ & $-185,106$ & 16 & 162,874 & $3,610,490$ & $-148,718$ \\
4 & 176,547 & $3,834,330$ & $-188,430$ & 17 & 159,995 & $3,592,440$ & $-154,861$ \\
5 & 176,526 & $3,815,150$ & $-191,908$ & 18 & 156,758 & $3,574,470$ & $-161,315$ \\
6 & 176,347 & $3,796,080$ & $-195,547$ & 19 & 153,138 & $3,556,600$ & $-168,099$ \\
7 & 175,997 & $3,777,100$ & $-199,357$ & 20 & 149,109 & $3,538,820$ & $-175,231$ \\
8 & 175,466 & $3,758,210$ & $-203,347$ & 21 & 144,645 & $3,521,120$ & $-182,731$ \\
9 & 174,739 & $3,739,420$ & $-207,528$ & 22 & 139,717 & $3,503,520$ & $-190,621$ \\
10 & 173,802 & $3,720,720$ & $-211,910$ & 23 & 134,294 & $3,486,000$ & $-198,921$ \\
11 & 172,641 & $3,702,120$ & $-216,503$ & 24 & 128,343 & $3,468,570$ & $-207,657$ \\
12 & 171,239 & $3,683,610$ & $-221,321$ & 25 & 121,831 & $3,451,230$ & $-198,384$ \\
\hline
\end{tabular}

annual energy production have been obtained as shown in Table 4. This energy output is calculated for lighting 4123 households and also found that one house consumes $914 \mathrm{kWh}$ per year. Since, ambient temperature for floating PV systems is lower as compared to that in case of onground PV systems, the energy output of former is found $11 \%$ more [10] and so calculated energy due to lower temperature effect is shown in an additional column in Table 4. Thus, extra average energy of $414,618 \mathrm{kWh} /$ year may be utilised to electrify another 454 houses. Extra energy production from floating PV system results in reduction of cost of energy per
$\mathrm{kWh}$ from $\$ 0.0598$ to $\$ 0.0538$ due to lower temperature benefit.

\section{Grid Extension Systems Results}

As specified earlier, erection of grid line along with solution of other social issues requires initial capital expenditure of $\$ 6.65$ billion. For the same load profile, number of $\mathrm{kWh}$ units supplied from grid is same as that from on-ground PV system. The price of grid electricity per $\mathrm{kWh}$ is taken to be $\$ 0.085$ which will be revenue for the generating unit. Taking profit on
Fig. 5 Month wise daily average Electricity from PV to village household loads
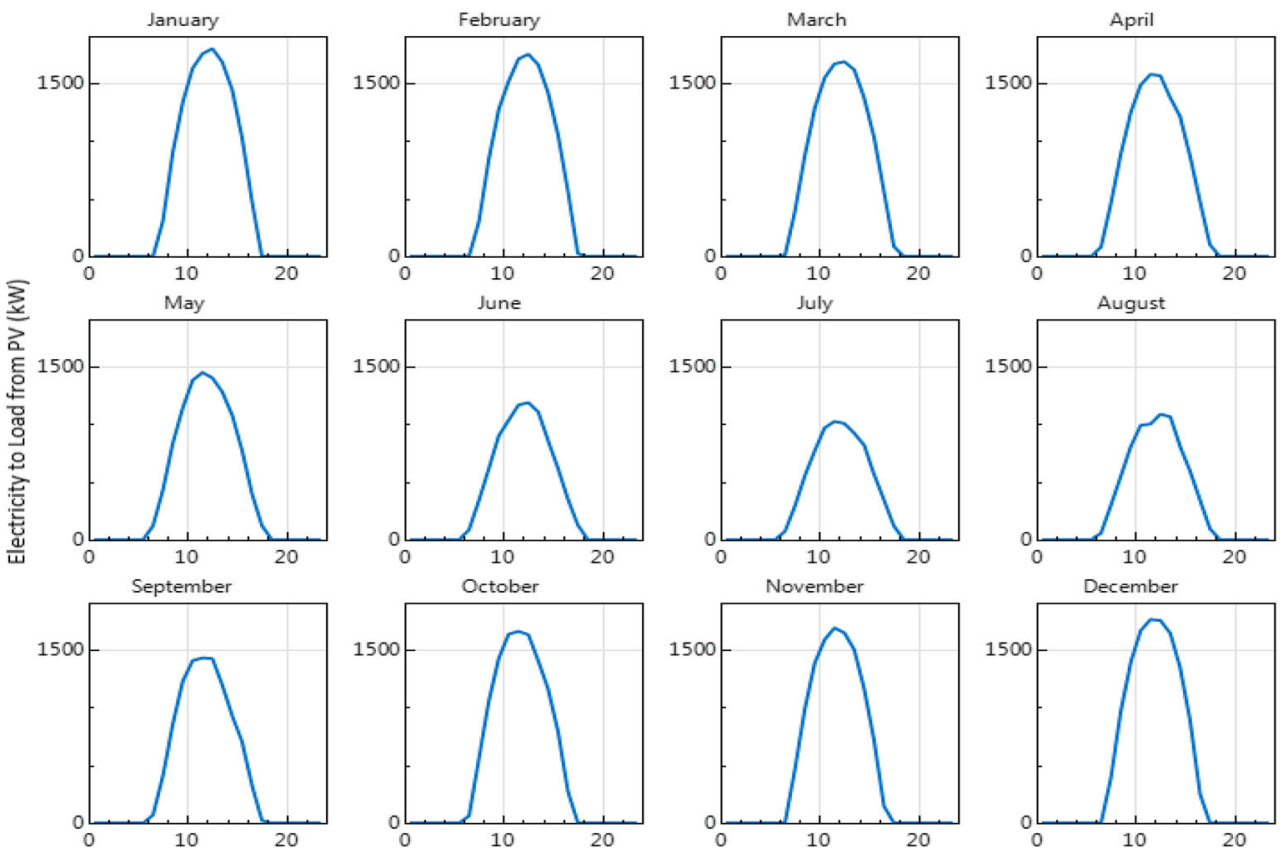
Table 4 Earnings, costs and energy produced during floating PV system lifetime of 25 years

\begin{tabular}{|c|c|c|c|c|c|c|c|c|c|}
\hline $\begin{array}{l}\text { Time } \\
\text { stamp }\end{array}$ & $\begin{array}{l}\text { EBITDA } \\
(\$)\end{array}$ & $\begin{array}{l}\text { Energy obtained } \\
\text { from simulation } \\
(\mathrm{kWh})\end{array}$ & $\begin{array}{l}\text { Calculated energy due } \\
\text { to lower temp. effect } \\
(\mathrm{kWh})\end{array}$ & $\begin{array}{l}\text { Annual } \\
\text { costs }(\$)\end{array}$ & $\begin{array}{l}\text { Time } \\
\text { stamp }\end{array}$ & $\begin{array}{l}\text { EBITDA } \\
(\$)\end{array}$ & $\begin{array}{l}\text { Energy obtained } \\
\text { from simulation } \\
(\mathrm{kWh})\end{array}$ & $\begin{array}{l}\text { Energy due to } \\
\text { lower temp. effect } \\
(\mathrm{kWh})\end{array}$ & $\begin{array}{l}\text { Annual } \\
\text { costs }(\$)\end{array}$ \\
\hline $\begin{array}{l}\text { Zero } \\
\text { ye- } \\
\text { ar }\end{array}$ & 0 & 0 & 0 & $-3,048,870$ & 13 & 245,513 & $3,768,640$ & $4,183,190$ & $-77,342.1$ \\
\hline 1 & 200,251 & $3,883,560$ & $4,310,752$ & $-99,649$ & 14 & 249,717 & $3,759,220$ & $4,172,734$ & $-78,956.6$ \\
\hline 2 & 203,681 & $3,873,850$ & $4,299,974$ & $-100,950$ & 15 & 253,992 & $3,749,820$ & $4,162,300$ & $-80,600.6$ \\
\hline 3 & 207,171 & $3,864,160$ & $4,289,218$ & $-102,274$ & 16 & 258,340 & $3,740,440$ & $4,151,888$ & $-82,274.4$ \\
\hline 4 & 210,719 & $3,854,500$ & $4,278,495$ & $-103,622$ & 17 & 262,762 & $3,731,090$ & $4,141,510$ & $-83,978.7$ \\
\hline 5 & 214,329 & $3,844,870$ & $4,267,806$ & $-104,995$ & 18 & 267,260 & $3,721,770$ & $4,131,165$ & $-85,714$ \\
\hline 6 & 218,000 & $3,835,250$ & $4,257,128$ & $-34,120.6$ & 19 & 271,834 & $3,712,460$ & $4,120,831$ & $-87,480.9$ \\
\hline 7 & 221,734 & $3,825,670$ & $4,246,494$ & $-35,543.7$ & 20 & 276,487 & $3,703,180$ & $4,110,530$ & $-89,279.9$ \\
\hline 8 & 225,531 & $3,816,100$ & $4,235,871$ & $-36,992.8$ & 21 & 281,218 & $3,693,920$ & $4,100,251$ & $-91,111.7$ \\
\hline 9 & 229,393 & $3,806,560$ & $4,225,282$ & $-38,468.1$ & 22 & 286,031 & $3,684,690$ & $4,090,006$ & $-92,976.8$ \\
\hline 10 & 233,322 & $3,797,050$ & $4,214,726$ & $-39,970.3$ & 23 & 290,926 & $3,675,480$ & $4,079,783$ & $-94,875.9$ \\
\hline 11 & 237,317 & $3,787,550$ & $4,204,181$ & $-41,499.9$ & 24 & 295,904 & $3,666,290$ & $4,069,582$ & $-96,809.6$ \\
\hline 12 & 241,380 & $3,778,080$ & $4,193,669$ & $-43,057.3$ & 25 & 300,967 & $3,657,120$ & $4,059,403$ & $-94,368.9$ \\
\hline
\end{tabular}

sale equal to $20 \%$, the per unit grid electricity sale benefit would be $\$ 0.017$. Based on numbers of units generated per year and benefit per unit, loan real discount rate of $6 \%$, the year wise revenue and cost incurred have been calculated to get net present value (NPV) [23].

$\mathrm{NPV}=\sum_{\mathrm{t}=1}^{\mathrm{N}} \frac{\mathrm{R}_{\mathrm{t}}-\mathrm{C}_{\mathrm{t}}}{(1+\mathrm{i})^{\mathrm{t}}}-\mathrm{I}_{0}$

where $C_{t}$ and $R_{t}$ are cost and revenue in $t^{\text {th }}$ year respectively, $N$ is project lifetime in years, $\mathrm{I}_{0}$ is the initial capital cost and $\mathrm{i}$ is the real discount rate. After putting all the data, the NPV has been calculated to be negative and equal to $\$ 6,649,988,981$ for considered project life of 25 years. The internal rate of return (IRR) is the discount rate at which NPV calculation is zero, i.e. when costs will become equal to benefits. IRR could not be achieved in the lifetime of 25 years of the project.

\section{Feasibility Comparative Analysis among Three Systems}

As discussed in previous sections, the results of three systems have been obtained. Based on few selected key parameters, the comparative analysis is shown in Table 5. As seen from the table, the floating PV system has lowest cost of energy along with its positive impact on society and environment. Floating PV system is acceptable to society because it does not require deforestation which affects livelihood of local people. NPV for all the systems is found negative for 25 years of project lifetime but this is found lowest for floating PV system. However, it is found that floating PV system achieves positive NPV of $\$ 38,968$ in 28th year of project life. Positive NPV for on-ground PV system and grid extension could not be achieved even after 50 years for project inception. Better cost parameters for floating PV system in spite of its higher

Table 5 Comparison of three systems based on key parameters

\begin{tabular}{llll}
\hline Key parameters & On-ground PV & Floating PV & Grid extension \\
\hline $\mathrm{NPV}(\$)$ & $-2,721,263$ & $-185,431$ & $-6,649,988,981$ \\
$\mathrm{IRR}$ & $-2.3 \%$ & $4.01 \%$ & Not achievable in project lifetime \\
Average energy produced per year $(\mathrm{kWh})$ & $3,667,586.4$ & $414,617.808$ & $3,667,586.4$ \\
Levelized cost of energy $(\$ \mathrm{kWh})$ & 0.0935 & 0.0598 & 0.085 \\
Feasibility with respect to social issues & Difficult & Feasible & Difficult \\
Impact on Environment & Conditionally Positive & Positive & Negative \\
$\mathrm{CO}_{2}$ emissions $(\mathrm{kg})$ & Nil & Nil & $3,777,614$ \\
\hline
\end{tabular}


Table 6 Sensitivity analysis for variation in solar radiations due to location change

\begin{tabular}{llllll}
\hline Key parameters & \multicolumn{2}{l}{ On-ground PV } & & \multicolumn{2}{l}{ Floating PV } \\
\cline { 2 - 3 } \cline { 5 - 6 } & ASR: $5.00 \mathrm{kWh} / \mathrm{m}^{2} / \mathrm{d}$ & ASR: $5.47 \mathrm{kWh} / \mathrm{m}^{2} / \mathrm{d}$ & & ASR: $5.00 \mathrm{kWh} / \mathrm{m}^{2} / \mathrm{d}$ & $\mathrm{ASR}: 5.47 \mathrm{kWh} / \mathrm{m}^{2} / \mathrm{d}$ \\
\hline $\mathrm{NPV}(\$)$ & $-2,721,263$ & $-2,628,473$ & $-185,431$ & $-177,287$ \\
$\mathrm{IRR}$ & $-2.3 \%$ & $-2.21 \%$ & $4.01 \%$ & $4.37 \%$ \\
Average energy produced per year $(\mathrm{kWh})$ & $3,667,586.4$ & $3,941,656$ & $414,617.808$ & $447,123.844$ \\
Levelized cost of energy $(\$ \mathrm{kWh})$ & 0.0935 & 0.0928 & 0.0598 & 0.0542 \\
Feasibility with respect to social issues & Difficult & Difficult & Feasible & Feasible \\
Impact on environment & Conditionally positive & Conditionally positive & Positive & Positive \\
$\mathrm{CO}_{2}$ emissions $(\mathrm{kg})$ & Nil & Nil & Nil & Nil \\
\hline
\end{tabular}

installation costs are due to its higher efficiency and capital cost saving for no land requirement in its erection. Floating PV systems also help increase reservoir water level which will increase power generation capacity of a hydro power plant if installed on it. The on-ground PV system's impact on environment is conditionally positive since it depends on trade-off between its clean energy production and amount of deforestation performed.

Since PV is an intermittent source and the solar radiations vary with location, a sensitivity analysis has been performed for changing solar radiations with change in latitude and longitude. The effect of variations in average solar radiations (ASR) on various parameters has been shown in Table 6 for both on-ground PV and floating PV systems. It can be seen that as the solar radiations increase from 5 to $5.47 \mathrm{kWh} / \mathrm{m}^{2} / \mathrm{d}$, the effect is positive on both the systems with respect to all the parameters i.e. NPV, IRR, average energy produced per year and levelized cost of energy.

\section{Conclusion}

The problem of electrification of a remote village of Chhattisgarh state in India was addressed by analysing three systems feasibility analysis from technical, economical and social point of view. The three systems considered were onground PV system, floating PV system and grid extension system. Two PV systems were designed and simulated using SAM software and their results were compared with grid extension systems parameters also. Key parameters selected for comparative analysis were NPV, IRR, cost of energy, social acceptance, impact on environment and $\mathrm{CO}_{2}$ emissions. From all the aspects, floating PV system was found best feasible solution. NPV for all the systems were found negative in 25 years of project life but floating PV systems attains positive NPV in 28th year of its lifetime. In the world, there are many places where deforestation is of great concern from environmental aspects, grid extension and on-ground PV system may not be feasible options. Thus floating PV systems can be a proven way to solve electrification issues of very remote and dense forest areas availing water reservoirs.

\section{References}

1. Central Electricity Authority (CEA), Draft National Electricity plan 1(2016) New Delhi, India

2. International Energy Agency (World Energy Outlook report 2020) https://www.iea.org/reports/world-energy-outlook-2020

3. Niti Aayog (National Institute for Transforming India, Govt. of India) http://niti.gov.in/best-practices/district-wise-statistics\#

4. $24 \times 7$ Power for All, A joint report of Ministry of Power, Govt. of India and Govt. of Chhattisgarh, http://powermin.nic.in/sites/ default/files/uploads/joint_initiative_of_govt_of_india_ and chhattisgarh.pdf

5. Adefarati T, Bansal RC (2016) Integration of renewable distributed generators into the distribution system: a review. IET-Renewable Power Gener 10(7):873-884

6. Malakar Y (2018) Evaluating the role of rural electrification in expanding people's capabilities in India. Energy Policy 114:492498

7. Saxena V, Bhattacharya PC (2018) Inequalities in LPG and electricity consumption in India: the role of caste, tribe, and religion. Energy Sustain Dev 42:44-53

8. Aklin M, Cheng CY, Urpelainen J (2018) Geography, community, household: adoption of distributed solar power across India. Energy Sustain Dev 42:54-63

9. Sahu A, Yadav N, Sudhakar K (2016) Floating photovoltaic power plant: a review. Renew Sust Energ Rev 66:815-824

10. Choi, Y.K. (2014) A study on power generation analysis of floating PV system considering environmental impact. Republic of Korea

11. Ferrer-Gisbert C, Ferrán-Gozálvez JJ, Redón-Santafé M, FerrerGisbert P, Sánchez-Romero FJ, Torregrosa-Soler JB (2013) A new photovoltaic floating cover system for water reservoirs. Renew Energy 60:63-70

12. Song J, Choi Y (2016) Analysis of the potential for use of floating photovoltaic systems on mine pit lakes: case study at the Ssangyong open-pit limestone mine in Korea. Energies 9(2):102 1-13

13. Kumar BS, Sudhakar K (2015) Performance evaluation of 10 MW grid connected solar photovoltaic power plant in India. Energy Rep $1: 184-192$ 
14. Adefarati T, Bansal RC (2019) Reliability, economic and environmental analysis of a microgrid system in the presence of renewable energy resources. Appl Energy 236(2019):1089-1114

15. Razmjoo AA, Davarpanah A (2019) The role of renewable energy to achieve energy sustainability in Iran. An economic and technical analysis of the hybrid power system. Technol Econ Smart Grids Sustain Energy 4(1):7

16. Kumar P, Palwalia DK (2018) Feasibility study of standalone hybrid wind-PV-battery microgrid operation. Technol Econ Smart Grids Sustain Energy 3(1):17

17. Gorjian, S., Sharon, H., Ebadi, H., Kant, K., Scavo, F.B. and Tina, G.M., 2020 Recent technical advancements, economics and environmental impacts of floating photovoltaic solar energy conversion systems. J Clean Prod: 124285

18. Website of National Aeronautics and Space Administration (NASA), USA, https://eosweb.larc.nasa.gov/cgi-in/sse/grid.cgi? \&num $=262110 \&$ lat $=19.451 \&$ hgt $=100 \&$ submit=Submit $\& v e g=$ $17 \&$ sitelev=\&email=skip @larc.nasa.gov\&p=grid id \&step= $2 \&$ lon $=81.868$
19. Website of Environmental Systems Research Institute (ESRI), $\mathrm{http}: / / \mathrm{www}$.esri.com/arcgis/about- arcgis

20. Website of Regional Centre for Development Corporation, http:// www.banajata.org/pdf/case-studies/chattisgarh.pdf

21. System advisor model documentation, https://sam.nrel.gov/ photovoltaic/pv-sub-page-2.html

22. Kim SH, Yoon SJ, Choi W (2017) Design and construction of 1 MW class floating PV generation structural system using FRP members. Energies 10(8):1142 1-14

23. Baneshi M, Hadianfard F (2016) Techno-economic feasibility of hybrid diesel/PV/wind/battery electricity generation systems for non-residential large electricity consumers under southern Iran climate conditions. Energy Convers Manag 127:233-244

Publisher's Note Springer Nature remains neutral with regard to jurisdictional claims in published maps and institutional affiliations. 